\title{
Production and characterization of Newcastle disease antibody as a reagent to develop a rapid immunodiagnostic test tool
}

\author{
Dwi Desmiyeni Putri ${ }^{1}$, Ekowati Handharyani ${ }^{2}$, Retno Damajanti Soejoedono ${ }^{3}$, Agus Setiyono ${ }^{2}$ and Okti Nadia Poetri ${ }^{3}$
}

1. Study Program of Animal Husbandry, Department of Animal Husbandry, State Polytechnic of Lampung, Indonesia;

2. Department of Veterinary Clinic Reproduction and Pathology, Faculty of Veterinary Medicine, Bogor Agricultural University, Indonesia; 3. Department of Animal Diseases and Veterinary Public Health, Faculty of Veterinary Medicine, Bogor Agricultural University, Indonesia.

Corresponding author: Dwi Desmiyeni Putri, e-mail: desmiyenidwi@gmail.com

Co-authors: EH: ekowatieko@apps.ipb.ac.id, RDS: retnodmail@yahoo.com, AS: agusetiyo@yahoo.com, ONP: diapoetri@gmail.com

Received: 19-01-2018, Accepted: 24-05-2018, Published online: 05-07-2018

doi: 10.14202/vetworld.2018.895-901 How to cite this article: Putri DD, Handharyani E, Soejoedono RD, Setiyono A, Poetri ON (2018) Production and characterization of Newcastle disease antibody as a reagent to develop a rapid immunodiagnostic test tool, Veterinary World, 11(7): 895-901.

\begin{abstract}
Aim: This research was conducted to produce and characterize ND antibody as reagent candidate to develop a rapid immunodiagnostic test tool.

Materials and Methods: Four New Zealand White rabbits were used in this study and divided into two groups. First group was injected by Sato ND antigen, and second group was injected by genotype VII ND antigen. This study is divided into three steps: (a) ND antibody production, (b) ND antibody purification, and (c) ND antibody characterization. First group was rabbit injected by Sato NDV $\left(5 \times 10^{8.25}\right.$ egg lethal doses $\left.(\mathrm{ELD})_{50} / \mathrm{ml}\right)$ and second group was injected by genotype VII NDV $\left(5 \times 10^{6.5} \mathrm{ELD}_{50} / \mathrm{ml}\right)$. Antigen induction was performed by subcutaneous administrated for first (day 1$)$ and second (day 14$)$ injection and intravenous administrated for third (day 30) injection. Blood was collected on day 8 after third injection.
\end{abstract}

Results: Antibody production increased on second antigen injection and reached a peak on day 9 after second antigen injection. Sato and genotype VII ND antibody can be produced without adjuvant within 38 days with the highest titer $2^{10}$. Based on antibody titer data, both antigens induced antibody production in a similar trend. The characterization antibody by SDS-PAGE indicated that molecular weight of immunoglobulin $\mathrm{G}(\mathrm{IgG})$ is $154.93 \mathrm{kDa}$ (whole IgG), heavy chain $54.39 \mathrm{kDa}$, and light chain $27.74 \mathrm{kDa}$. ND antibodies have specificity to homologous and heterologous NDVs in varying virulence.

Conclusion: Sato and genotype VII ND antibodies have been successfully produced within 38 days without adjuvant. Specificity of ND antibodies to NDVs in varying virulence and cross-reaction between Sato ND antibody and genotype VII ND antibody indicates that the characterized ND antibodies can be used as a reagent to develop rapid immunodiagnostic test tools.

Keywords: antibody, cross reaction, reagent, SDS-PAGE.

\section{Introduction}

Newcastle disease (ND) is one of the important poultry diseases in the world which caused by ND virus (NDV) and also known as avian paramyxovirus type-1 (APMV-1) [1,2]. The virus has six major proteins: nucleocapsid protein $(\mathrm{N})$, phosphoprotein $(\mathrm{P})$, matrix protein $(\mathrm{M})$, fusion protein $(\mathrm{F})$, hemagglutinin-neuraminidase protein, and large polymerase protein (L) [3]. Based on genotype, NDV can be divided into two classes. Class 1 is commonly found in waterfowl and avirulent in chicken, whereas Class 2 NDV consists of 16 genotypes which are commonly found in chicken, pet birds, and wild poultry [4].

The first ND outbreak was occurred in Java Island (Indonesia) and the United Kingdom, reported

Copyright: Putri, et al. Open Access. This article is distributed under the terms of the Creative Commons Attribution 4.0 International License (http://creativecommons.org/licenses/by/4.0/), which permits unrestricted use, distribution, and reproduction in any medium, provided you give appropriate credit to the original author(s) and the source, provide a link to the Creative Commons license, and indicate if changes were made. The Creative Commons Public Domain Dedication waiver (http://creativecommons.org/ publicdomain/zero/1.0/) applies to the data made available in this article, unless otherwise stated. in the mid-1920s [5]. In a few years, the disease spread worldwide and became endemic in many countries [6]. Currently, almost all areas in Indonesia are infected, and until now, there is no free area ND in Indonesia.

In developing countries, the losses caused by ND outbreaks are not only due to high mortality but also additional expenditure used for prevention and control programs, i.e., vaccination, biosecurity, and depopulation [7]. However, the right control strategy can be done if the disease diagnosis can be done quickly and precisely.

Disease diagnosis can be done through a series of activities involving observation of clinical symptoms, histopathological lesion, and laboratory tests [8,9]. However, the similarity of clinical symptoms and gross lesions in ND-infected chicken with other diseases can be confusing in determining the proper diagnosis. Recently, we have developed a method to detect NDV using reverse transcriptase-polymerase chain reaction (RT-PCR) diagnostic tool [10]. However, RT-PCR method requires special facilities and high cost relatively that is one of the inhibiting factors in 
decision-making to control ND outbreak in the field. Therefore, in field, fast and affordable diagnostic test tool is necessary.

This research was conducted to produce and characterize ND antibody as reagent candidate to develop rapid immunodiagnostic test tool.

\section{Materials and Methods}

\section{Ethical approval}

This research has been approved by the Animal Care and Use Committee of Research and Community Services Institution, Bogor Agricultural University, with approval number: 3-2016 RSHP FKH-IPB.

\section{NDV}

Two NDVs were used in this study. First virus was NDV/Ck/BGR/2011 obtained from repository of the Laboratory of Immunology, Faculty of Veterinary Medicine, Bogor Agricultural University, which categorized as virulent NDV and belongs to genotype VII NDV $[11,12]$. Another virus was Sato NDV which obtained from the National Veterinary Drug and Assay Laboratory, Gunung Sindur, Bogor, Indonesia.

\section{Experimental animal}

Experimental animals used in this study were four New Zealand White rabbits aged 10-16 weeks with an average body weight of $2.5 \mathrm{~kg}$ obtained from the Indonesian Animal Husbandry Research Institute, Ciawi, Bogor, Indonesia.

\section{Research design}

This study is divided into three stages: (a) ND antibody production, (b) ND antibody purification, and (c) ND antibody characterization.

\section{ND antibody production}

ND antibody production was performed in four New Zealand White rabbits which divided into two groups. First group was rabbit injected by Sato NDV $\left(5 \times 10^{8.25}\right.$ embryo lethal dose $\left.[\mathrm{ELD}]_{50} / \mathrm{ml}\right)$ and second group was injected by genotype VII NDV $\left(5 \times 10^{6.5} \mathrm{ELD}_{50} / \mathrm{ml}\right)$. Antigen was administrated by subcutaneous in first (day 1) and second (day 14) injection and intravenous in third (day 30) injection. Blood was collected on day 8 after third injection. Bleeding is performed by taking blood intracardially after the rabbits had been anesthetized with a ketamine $(35 \mathrm{mg} / \mathrm{kg} \mathrm{BB})$ and xylazine $(5 \mathrm{mg} / \mathrm{kg} \mathrm{BB})$ mixture. The collected blood was prepared as follows: The blood samples were stored at room temperature $\left( \pm 25^{\circ} \mathrm{C}\right)$ for an hour and continued storage at $4^{\circ} \mathrm{C}$ overnight. The obtained serum was separated manually by aspiration and was completed by centrifugation at $2500 \mathrm{rpm}$ for $15 \mathrm{~min}$. The obtained serum was stored in $1.5 \mathrm{ml}$ polypropylene microcentrifuge tubes and stored at $-20^{\circ} \mathrm{C}$ until use. To analyze antibody titer by hemagglutination inhibition test, blood was collected on day 12 after the first injection, days 5,9 , and 16 after second injection, and days 3, 5, and 8 after third injection.

\section{ND antibody purification}

The purification of ND antibody was performed by two steps. The first step is precipitation with ammonium sulfate according to Duong-Ly and Gabelli [13]. Precipitation using ammonium sulfate $(4.1 \mathrm{M})$ was carried out by adding ammonium sulfate solution to serum and then incubating overnight at $4{ }^{\circ} \mathrm{C}$. The precipitation result was centrifuged at $3.000 \times \mathrm{g}$ for $20 \mathrm{~min}$. The obtained filtrate or pellet was reconstituted by phosphate buffered saline (PBS) $\mathrm{pH} 7.4$ to obtain one-fourth of antibody volume. Subsequently, dialysis was performed by preparing a precipitated serum in a dialysis sac (Spectra/Por, USA) and stirred in $\mathrm{pH} 7.4$ of $\mathrm{PBS}$ for $24 \mathrm{~h}$ at $4^{\circ} \mathrm{C}$ and each $8 \mathrm{~h}$ PBS solution was replaced. Following the first step, the next antibody purification process used protein A purification kit (Sigma, USA) according to the manufacturer's instructions. Purification results were examined by sodium dodecyl sulfate-polyacrylamide gel electrophoresis (SDS-PAGE) method. The protein concentration was calculated using coefficient 1.36 at $280 \mathrm{~nm}$ wavelength [14].

\section{ND antibody characterization}

Purified ND antibody molecular weight was determined by SDS-PAGE method [15] using 12\% polyacrylamide concentration of separating gel and $4 \%$ concentration of stacking gel [16]. The antibody sample $(5 \mu \mathrm{l})$ was added to $5 \mu \mathrm{l}$ sample buffer (containing Tris/SDS, bromophenol blue, DTT, and glycerol) and then heated at $60^{\circ} \mathrm{C}$ for $5 \mathrm{~min}$. A total of $10 \mu \mathrm{l}$ antibody samples and $5 \mu 1$ protein markers (PageRuler Prestructive Protein Ladder, Thermo Scientific, USA) were filled in each well. Protein separation was performed by electrophoresis at $100 \mathrm{~V}$ for $180 \mathrm{~min}$. The electrophoresis gel was stained with Coomassie Blue for $30 \mathrm{~min}$ followed by destaining for $24 \mathrm{~h}$.

Agar gel precipitation test (AGPT) was used to determine the specificity of ND antibody. Specificity of ND antibody was evaluated to some characterized ND isolates [11] and other antigens such as avian influenza (AI), infectious bronchitis (IB), and infectious bursal disease (IBD). The antigen and antibody reaction was showed as precipitation line in agarose gel.

\section{Results}

\section{ND antibody production}

The ND antigens which used in this study were Sato NDV and genotype VII NDV [11]. ND antigens injection were performed 3 times, and serum was collected on day 8 after third injection. Antibody titer result after ND antigen injection in each group was determined by HI test (Figure-1). Based on HI titer, rabbits injected with Sato ND antigen and genotype VII ND antigen showed that antibodies were detected on day 12 after first injection, although the antibody titer in each group is still low $2^{4}-2^{5}$. The antibody titer increased after second antigen injection (first boosting) and reached a peak on day 9 in group which 
injected with Sato ND antigen and on day 5 in rabbits which injected by genotype VII ND antigen. After the third antigen injection, antibody production in rabbits which injected by genotype VII ND increased on day 3 and continued until day 8; nevertheless, antibody production in the rabbits which injected by Sato ND antigen is still constant after day 5 .

\section{ND antibody purification}

In this study, the antibody purification was done in two steps using ammonium sulfate $(4.1 \mathrm{M})$ and protein A purification kit (Sigma). The antibody concentration on rabbit serum was determined by UV/ Vis spectrophotometer at $280 \mathrm{~nm}$ wavelength $[17,18]$. Utilization of ammonium sulfate $40 \%$ is expected to precipitate immunoglobulin $\mathrm{G}$ ( $\mathrm{IgG}$ ) optimally. Based on the UV/Vis spectrophotometer, the result showed the Sato ND antibody concentration of $1.76 \mu \mathrm{g} / \mu$ land genotype VII ND antibody concentration of $1.82 \mu \mathrm{g} / \mu \mathrm{l}$.

The antibody purification using protein A purification kit produced several fractions. The fraction pattern of protein A purification result was different in each antibody. Sato ND antibody has the higher antibody concentration in fraction 7, 8, and 9 (Figure-2a), and the total amount of purified Sato ND antibody was $3.476 \mu \mathrm{g} / \mu \mathrm{l}$ (Table-1). The higher concentration

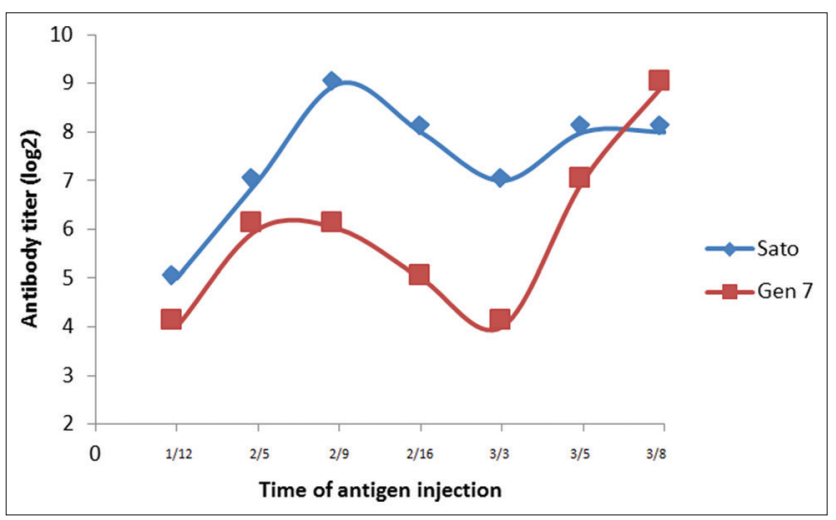

Figure-1: Titer of Newcastle disease antibodies after antigen injection. of ND genotype VII antibody found in fractions 5, 6 , and 7 (Figure-2b), and the total amount of purified ND antibody concentration was $3.574 \mu \mathrm{g} / \mu \mathrm{l}$ (Table-1).

\section{ND antibody characterization}

A purified antibody with ammonium sulfate $(4.1 \mathrm{M})$ and protein A purification kit was analyzed to determine molecular weight by SDS-PAGE. Electrophoresis results of SDS-PAGE showed that antibody purification with ammonium sulfate had 7 protein bands and serum which had passed through 2 purification steps had 4 protein bands only, while standard antibody had three protein bands (Figure-3). Determination of molecular weight in SDS-PAGE bands was performed by making a linear curve on the calculation of relative mobility value (Rf) and protein molecular weight molecule logarithm. Relative mobility (Rf) calculation and band molecular weight logarithm were obtained through linear regression curve with equation $\mathrm{y}=-0.2165 \mathrm{x}+2.2919 ; \mathrm{R}^{2}=0.9141$ (Table-2). Based on the regression equation, we found that the molecular weight of standard antibody was $154.93 \mathrm{kDa}, 54.39 \mathrm{kDa}$, and $24.74 \mathrm{kDa}$ for whole IgG, heavy chain $\mathrm{IgG}$, and light chain $\mathrm{IgG}$, respectively (Table-3).

\section{Specificity test of antibodies}

Sato and genotype VII ND antibodies were evaluated for specificity to some characterized ND isolates [11] and other antigens such as AI, IB, and IBD using AGPT. The indicator of antigen-antibody reaction at this stage was precipitation line in agarose gel. Based on AGPT result, the precipitation line was formed on all homologous and heterologous ND antigens with varying degrees of virulence (Figure-4), whereas in wells given AI, IB, and IBD antigens, we cannot found the precipitation line (Figure-5).

\section{Discussion}

Recently, the production of antibody in laboratory animals has become an essential part of many research projects. Investigators preparing to produce antibodies are confronted with a number of complex

Table-1: Absorbance rate and antibody level after purification.

\begin{tabular}{|c|c|c|c|c|}
\hline \multirow[t]{2}{*}{ Fraction } & \multicolumn{2}{|c|}{ Sato ND antibody } & \multicolumn{2}{|c|}{ Genotype VII ND antibody } \\
\hline & $\begin{array}{c}\text { Absorbance value } \\
(280 \mathrm{~nm})\end{array}$ & $\begin{array}{l}\text { Levels of antibodies } \\
(\mathrm{mg} / \mathrm{ml})\end{array}$ & $\begin{array}{c}\text { Absorbance value } \\
(280 \mathrm{~nm})\end{array}$ & $\begin{array}{c}\text { Levels of antibodies } \\
(\mathrm{mg} / \mathrm{ml})\end{array}$ \\
\hline 1 & 0.046 & 0.034 & 0.079 & 0.058 \\
\hline 2 & 0.042 & 0.031 & 0.060 & 0.044 \\
\hline 3 & 0.041 & 0.030 & 0.094 & 0.069 \\
\hline 4 & 0.074 & 0,054 & 0.122 & 0.089 \\
\hline 5 & 0.064 & 0.047 & 0.714 & 0.525 \\
\hline 6 & 0.241 & 0.177 & 1.150 & 0.846 \\
\hline 7 & 1.003 & 0.738 & 1.885 & 1.386 \\
\hline 8 & 1.394 & 1.025 & 0.486 & 0.357 \\
\hline 9 & 0.862 & 0.634 & 0.122 & 0.089 \\
\hline 10 & 0.555 & 0.408 & 0.055 & 0.041 \\
\hline 11 & 0.285 & 0.210 & 0.050 & 0.037 \\
\hline \multirow[t]{2}{*}{12} & 0.193 & 0.142 & 0.045 & 0.033 \\
\hline & Total & 3.476 & & 3.574 \\
\hline
\end{tabular}




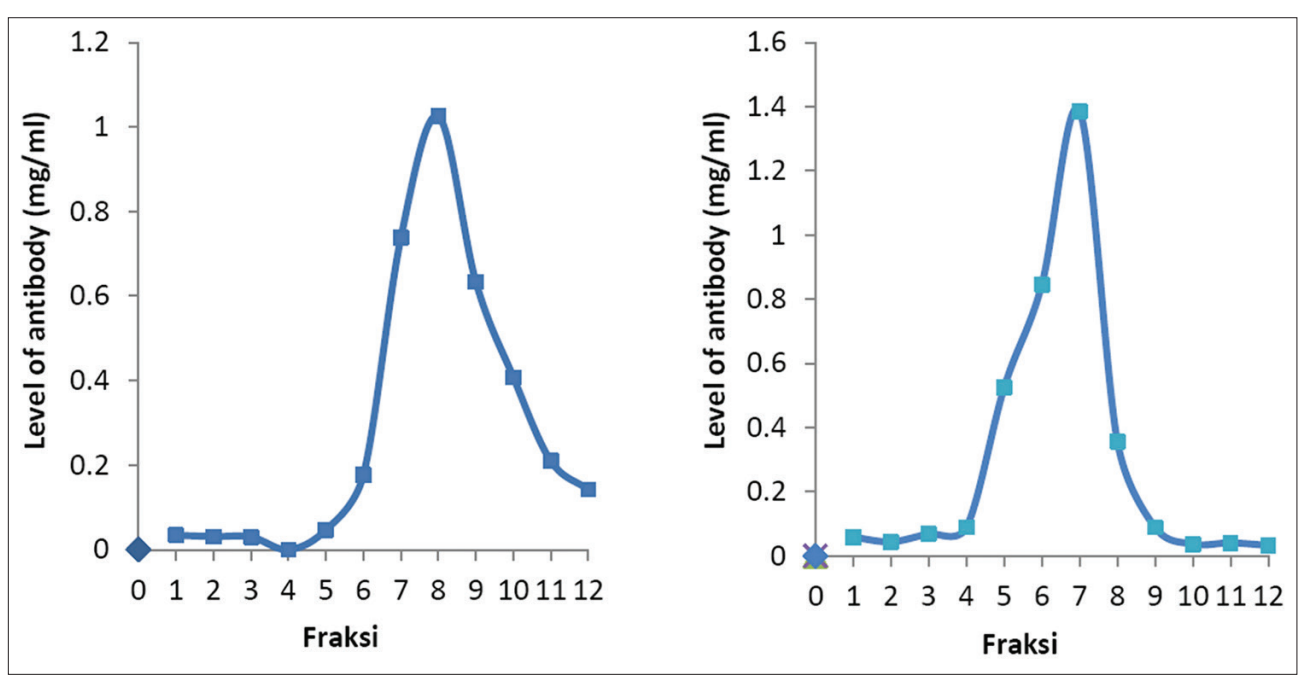

Figure-2: Pattern of Newcastle disease (ND) antibody fraction after purification; (a) Sato ND antibody; (b) Genotype VII ND antibody.

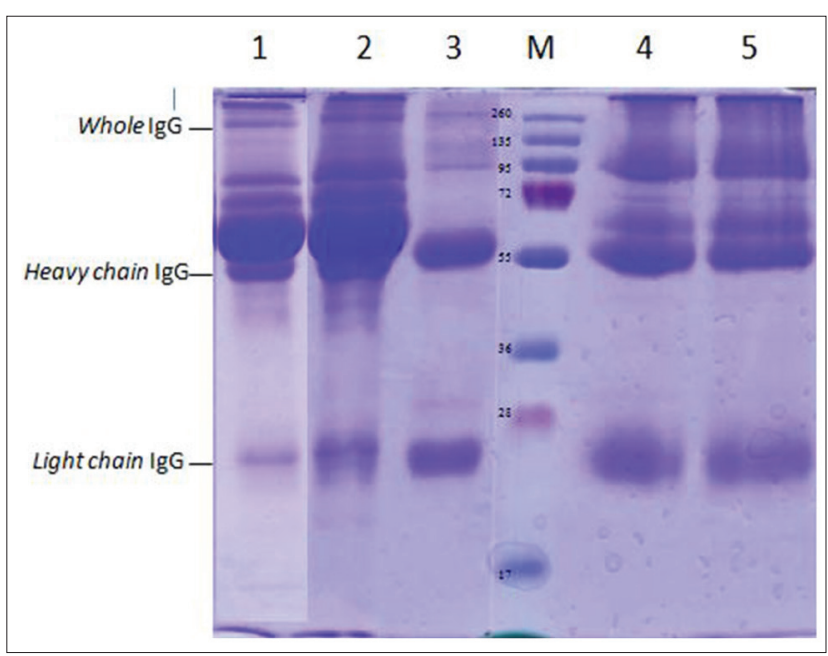

Figure-3: Profile of sodium dodecyl sulfate-polyacrylamide gel electrophoresis Newcastle disease (ND) antibody before purification (1-2) and after purification with protein purification kit A (4-5). Protein marker (M); Sato ND antibody (1 and 4); Genotype ND VII antibody (2 and 5); and commercial standard antibody (3).
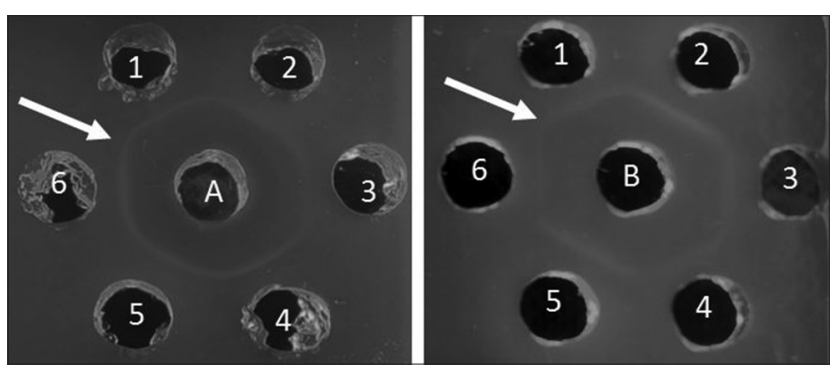

Figure-4: Antibody specificity test with agar gel precipitation test; A. Sato ND serum; B. Genotype VII NDserum; 1-6 Antigen ND. (1) ND/Ck/LG/15; (2) ND/Ck/ $\mathrm{GS} / 14$; (3) ND/Ck/JP/14; (4) ND/Ck/CJR/15; (5) ND/Ck/ Bogor/15; (6) ND/Ck/TRG/15. Arrow (): Precipitation line.

choices, some of which may be critical for success. The main goal in antibody production is to obtain high-titer, high-specificity antibody and still concerned in animal welfare. An antibody which produced should be induced by characterized antigen and
Table-2: Determination of equations based on linear curves.

\begin{tabular}{lcc}
\hline $\mathbf{R f}(\mathbf{c m})$ & BM $(\mathbf{k D a})$ & Log BM \\
\hline 0.31 & 260 & 2.4150 \\
0.65 & 135 & 2.1303 \\
1.11 & 95 & 1.9777 \\
1.64 & 72 & 1.8573 \\
2.23 & 52 & 1.7160 \\
2.96 & 42 & 1.6232 \\
3.58 & 34 & 1.5315 \\
4.47 & 26 & 1.4150 \\
\hline
\end{tabular}

$y=-0.2165 x+2.2919$

Table-3: Calculation of protein molecular weight band in SDS-PAGE analysis of ND antibody.

\begin{tabular}{lcc}
\hline Rf $\mathbf{( c m )}$ & BM $(\mathbf{k D a})$ & Log $\mathbf{B M}$ \\
\hline Ammonium sulfate & & \\
0.47 & 154.93 & 2.19 \\
1.11 & 112.61 & 2.05 \\
1.36 & 99.42 & 2.00 \\
1.91 & 75.58 & 1.88 \\
2.33 & 61.30 & 1.79 \\
2.57 & 54.39 & 1.74 \\
4.15 & 24.74 & 1.39 \\
Protein A & & \\
0.47 & 154.93 & 2.19 \\
2.33 & 61.30 & 1.79 \\
2.57 & 54.39 & 1.74 \\
4.15 & 24.74 & 1.39 \\
\hline
\end{tabular}

SDS: Sodium dodecyl sulfate-polyacrylamide gel electrophoresis, ND: Newcastle disease

also be characterized before used as a reagent in the immunodiagnostic test.

In this study, antibody has been successfully produced within 38 days with 3 times antigen injection. First injection in antibody production aims to introduce antigen to B cell; second and third injections are booster to increase antibody production by B cells $[19,20]$. In general, antibody begins to be detected in serum on day 6-7 after antigen exposure [21]. In the first antigen injection, the rabbits which injected by 

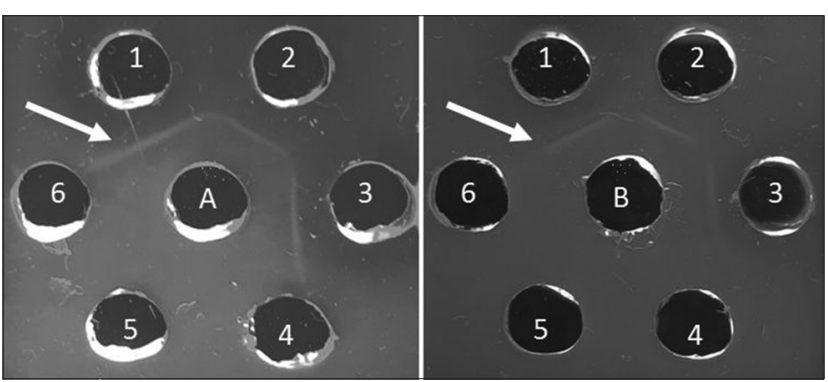

Figure-5: Antibody specificity test with agar gel precipitation test; (a) Sato ND serum; (b) Genotype VII ND serum; (1) Sato ND; (2) Genotype VII ND; (3) Lasota ND; (4) avian influenza virus; (5) infectious bronchitis virus; (6) infectious bursal disease virus. Arrow (): Precipitation line.

Sato ND antigen produced higher antibody than rabbits which injected by genotype VII ND antigen. The number of viruses were injected caused this phenomenon, the rabbits which injected by Sato ND antigen received $5 \times 10^{8.25}$ virus $/ \mathrm{ml} \mathrm{ELD}_{50}$, while the rabbits which injected by genotype VII ND antigen received $5 \times 10^{6.5}$ virus $/ \mathrm{ml} \mathrm{ELD}_{50}$ only. The third injection was performed after ND antibody titer decreased on day 16 after second injection. The second antigen exposure (booster) will activate memory cells and produce antibody faster as a secondary response [22]. In general, reinjection of antigen (booster) is performed at weeks 3 and 6 after first injection and when antibody titers begin to decline [23]. Based on Figure-1 showed that, antibody titer of rabbits which injected by Sato ND antigen was still high (27) when third antigen injection. Antigens that given will be neutralized by antibody, so only a few antigens can induce subsequent immunologic responses. Neutralization is antibody activities to bind and neutralize the viral surface (virion) to decrease virus ability to infect [24].

Antibody production in both the groups increased rapidly after the third injection by intravenous administrated route. The effectivity of the immune response to produce antibody is determined by the speed of antigen reaching lymphoid organ. By intravenous immunization, antigens reach to spleen and lymph nodes immediately [25]. Antibody production in vaccinated animals may be affected by several factors including immunogenicity, antigen quality and quantity, antigen form and solubility, animal species, and immunization route[26]. ND antibody production in this study was done in 38 days only and more economical with no adjuvant needed. Samiullah et al. [27] showed that antibody to APMV-1 can be produced within 91 days using adjuvant and reach titer $1024\left(2^{10}\right)$ with 4 and 5 times injection.

The antibody has to be separated from another component in serum before be characterized. Separation of antibodies from complex mixtures can be achieved using some purification method [28]. In this study, antibody passed two-step purification. First step of antibody purification used ammonium sulfate. Antibody purification using ammonium sulfate is one of the oldest, easiest, and economical methods for purifying antibodies [29]. Ammonium sulfate has a higher solubility than other phosphate salts, which become preferred solutions for precipitation. The principle of antibody purification by ammonium sulfate is ammonium sulfate ability to bind $\operatorname{IgG}[30]$. According to Ausubel et al. [15], saturation $35-45 \%$ of ammonium sulfate can precipitate $80-90 \%$ of $\mathrm{IgG}$ in rabbit and sheep serum.

The second step of antibody purification was using protein A purification kit. Protein A is a surface protein in Staphylococcus aureus [31] which has 5 domains $\mathrm{E}, \mathrm{D}, \mathrm{A}, \mathrm{B}$, and $\mathrm{C}$ base on $\mathrm{N}$-terminus. Each domain of protein $\mathrm{A}$ is able to bind $\mathrm{Fc}$ fragment of $\operatorname{IgG}$ [32]. Purified antibodies were characterized by SDS-PAGE to determine the molecular weight of antibody. According to Johnson [33], molecular weight of $\mathrm{IgG}$ ranges from 150 to $160 \mathrm{kDa}$. Immunoglobulin $\mathrm{G}$ has a molecular weight of monomer structure 146,000 daltons, and it is the main antibody of the secondary immune response [34]. Chemical treated IgG molecules, such as SDS, will break the disulfide bond and cause the IgG molecules to break down into four separate polypeptide chains. These chains are "heavy" chain which has a molecular weight of about $50 \mathrm{kDa}$ and two other "light" chains which have a molecular weight of about $25 \mathrm{kDa}[35,36]$. In serum which purified by ammonium sulfate only, are still found some substances like transferrin, albumin, and other proteins at molecular weight $112.61 \mathrm{kDa}, 99.42 \mathrm{kDa}$, $75.5 \mathrm{kDa}$, and $61.30 \mathrm{kDa}$. Transferrin is a protein found in serum with a molecular weight of $75 \mathrm{kDa}$, and albumin has a molecular weight of $60 \mathrm{kDa}$ [37].

Proteins revealed by SDS-PAGE were not specific yet; therefore, specificity test is required to obtain a specific protein. In this study, antibody specificity was evaluated by AGPT. An antibody which induced by injection whole or partial antigen called as a polyclonal antibody. Polyclonal antibodies are antibodies that have a complex mixture of antibodies with different specificity, affinity, and isotype. Polyclonal antibodies have the function for binding various epitopes on the surface of the inducing antigen molecule [38]. Polyclonal antibodies react with different epitopes (antigen determinants) in multireactivity leading to cross-reactions. Cross-reaction occurs if the same epitope from different antigens which structurally similar are identified by antibodies. This principle can also be used to determine the relationship between antigen molecules [35]. NDV (APMV-1) is one serotype [7], so it will have a cross-reaction with the heterologous NDV [27]. Based on AGPT, the result showed that ND antibody which produced in this study could be used as a reagent to developed rapid immunodiagnostic test tool for testing either homologous ND or heterologous NDVs. Furthermore, these ND antibodies which produce in short time without adjuvant can be used commercially in developed immunodiagnostic test tools for ND. These future diagnostic kits can 
provide a fast, easy, cheap, and accurate detection of NDVs. Finally, the produced antibodies can be sold commercially as a positive control for immunological tests in laboratories.

\section{Conclusion}

The study succeeded in producing ND antibodies from Sato and genotype VII ND antigens. ND antibodies can be produced within 38 days without adjuvant with the highest titer of $2^{10}$. The characterization antibody by SDS-PAGE indicated that molecular weight of $\mathrm{IgG}$ is a $154.93 \mathrm{kDa}$, with heavy chain $54.39 \mathrm{kDa}$ and light chain $27.74 \mathrm{kDa}$. These antibodies are specific to homologous and heterologous NDVs with varying degrees of virulence.

\section{Authors' Contributions}

DDP executed the work (collection of data, analysis, and writing of manuscript); EH participated in conception and designed the study and drafting of the manuscript; AS participated in designing the study and drafting of the manuscript; RDS participated in designing the study, analysis of data, and drafting of the manuscript, ONP participated in analysis and interpretation of data and writing of manuscript. All authors read and approved the final manuscript.

\section{Acknowledgments}

This research was funded by Ministry of Research, Technology and Higher Education of Republic Indonesia in Hibah Bersaing Research Grant No 078.6/PL 15.8/LT/2017.

\section{Competing Interests} interests.

The authors declare that they have no competing

\section{References}

1. Ashraf, A. and Shah, M.S. (2014) Newcastle disease: Present status and future challenges for developing countries. Afr. J. Microbiol. Res., 8: 411-416.

2. Alexander D.J. and Jones R.C. (2008) In: Mark, P., Pau, F.M., Janet, M.B., Dennis, J.A., editor. Paramyxoviridae. Saunders, W.B, Edinburgh. p294-316.

3. Al-Habeeb, M.A., Mohamed, M.H.A. and Sharawi, S. (2013) Detection and characterization of Newcastle disease virus in clinical samples using real-time RT-PCR and melting curve analysis based on matrix and fusion genes amplification. Vet. World, 6: 239-243.

4. Diel, D.G., Susta, L., Cardenas, G.S., Killian, M.L., Brown, C.C., Miller, P.J. and Afonso, C.L. (2012) Complete genome and clinicopathological characterization of a virulent Newcastle disease virus isolate from South America. $J$. Clin. Microbiol., 50: 378-387.

5. Seal, B.S., King D.J. and Sellers H.S. (2000) The avian response to Newcastle disease virus. Dev. Com. Immunol., 24: $257-268$

6. Naveen, K.A., Singh, S.D., Kataria, J.M., Barathidasan, R. and Dhama, K. (2013) Detection and differentiation of pigeon paramyxovirus serotype-1(PPMV-1) isolates by RT-PCR and restriction enzyme analysis. Trop. Anim. Health. Prod., 45: 1231-1236.

7. Abdisa, T. and Tagesu, T (2013) Review on Newcastle disease of poultry and it's public health importance. J. Vet. Sci. Technol., 8(3): 1-7.
8. Cattoli, G., Susta, L., Terregino, C. and Brown, C. (2011) Newcastle disease: A review of field recognition and current methods of laboratory detection. J. Vet. Diag. Invest., 23(4): 637-656.

9. Office International des Epizooties (OIE). (2012) Newcastle Disease. OIE Terestrial Manual, France. p1-19.

10. Choi, K.S., Kye, S.J., Kim, J.Y., To, T.L., Nguyen, D.T., Lee, Y.J. and Lee, H.S. (2014) Molecular epidemiology of Newcastle disease viruses in Vietnam. Trop. Anim. Health Prod., 46(1): 271-277.

11. Putri, D.D., Handharyani, E., Soejono, R.D., Setiyono, A., Mayasari, N.I. and Poetri, O.N. (2017) Pathotypic characterization of Newcastle disease virus isolated from vaccinated chicken in West Java Indonesia. Vet. World, 10(4): 438-444.

12. Putri, D.D., Handharyani, E., Soejono, R.D., Setiyono, A. and Poetri, O.N. (2018) Genotypic characterization of Newcastle disease virus isolated from commercial flock chicken in West Java Indonesia. Pak. Vet. J., 38(2): 184-188.

13. Duong-Ly, K.C. and Gabelli, S.B. (2014) Salting out of protein using ammonium sulfate precipitation. Method. Enzymol., 541: 85-94.

14. Johnstone, A. and Thorpe, R. (1988) Immunochemistry in Practice. Blackwell Scientific Publications, Oxford, England.

15. Ausubel, F.M., Brent, R., Kingston, R.E., Moore, D.D., Seidman, J.G., Smith, J.A. and Struhl, K. (2003) Current Protocols in Molecular Biology. John Willey \& Sons, New York, US

16. Sambrook, J. and Russel, D.W. (2001) Molecular Cloning: A Laboratory Manual. Vol. 1. Cold Spring Harbour Lab Press, New York, USA.

17. Bergmann-Leitner, E.S., Mease, R.M., Duncan, E.H., Khan, F., Waitumbi, J. and Angov, E. (2008) Evaluation of immunoglobulin purification methods and their impact on quality and yield of antigen-specific antibodies. Malar J., 7: 129.

18. Green, M.R. and Sambrook, J. (2012) Molecular Cloning - A Laboratory Manual. $4^{\text {th }}$ ed. Cold Spring Habor Laboratory Press, Cold Spring Harbor, NY.

19. Nandin, I.S., Fong, C., Deantonio, C., Torreno-Pina, J.A., Pecetta, S., Maldonado, P., Gasparrini, F., Ordovas-Montanes, J., Kazer, S.W., Kjaer, S., Borley, D.W., Nair, U., Coleman, J.A., Lingwood, D., Shalek, A.K., Meffre, E., Poignard, P., Burton, D.R. and Batista, F.D. (2017) Novel in vitro booster vaccination to rapidly generate antigen-specific human monoclonal antibodies. J. Exp. Med., 2017: 1-20.

20. Nutt, S.L., Hodgkin, P.D., Tarlinton, D.M. and Corcoran, L.M. (2015) The generation of antibody-secreting plasma cells. Nat. Rev. Immunol., 15: 160-171.

21. Wibawan, I.W.T. and Soejoedono, R.D. (2013) Intisari Imunologi Medis. Faculty of Veterinary Medicine Press, Bogor, Indonesia. p35.

22. Yu. Y.H. and Lin, K.I. (2016) Factors that regulate the generation of antibody-secreting plasma cells. Adv. Immunol., 131: 61-99.

23. Hanley, W.C., Artwohl, J. and Bennett, B.T. (1995) Review of polyclonal antibody production procedures in mammals and poultry. Inst. Lab. Anim. Res. J., 37(3): 91-118.

24. Klasse, P.J. (2014) Neutralization of virus infectivity by antibodies: Old problems in new perspectives. J. Adv. Biol., 2014: $1-24$

25. Howard, G.C. and Kaser, M.R. (2006) Making and Using Antibodies: A Practical Handbook. CRC Press, Boca Raton.

26. Reverberi, R. and Reverberi, L. (2007) Factors affecting the antigen-antibody reaction. Blood Transfus., 5: 227-240.

27. Samiullah, M., Rizvi, F., Anjun, A.D. and Shah, M.F.A. (2006) Rising hyperimmune serum against avian paramyxovirus (APMV-1) and pigeon paramyxovirus (PPMV-1) in rabbits and their cross-reactivity. Pak. J. Biol. Sci., 9: 2184-2186.

28. Murphy, C., Devine, T. and O'Kennedy, R. (2016) 
Technology advancements in antibody purification. Dovepress, 2016: 17-32. Available from: https:/www. com/technology-advancements-in-antibody-purification-peer-reviewed-full. Accessed on 21-07-2017.

29. Wingfield, P.T. (2001) Protein precipitation using ammonium sulfate. Curr. Protoc. Protein Sci. Appendix-3F. Available from: https://www.ncbi.nlm.nih.gov/pmc/articles/PMC4817497. Accessed on 05-04-2017.

30. Page, M. and Thorppe, R. (2001) Purification of IgG by Precipitation with Sodium Sulfate or Ammonium Sulfate. In: Hage, D.S. editor. Handbook of Affinity Chromatography Book Chapter. $2^{\text {nd }}$ ed. Taylor and Francis Group. New York. Available from: https://www.books.google.co.id/books?id. Accessed on 05-07-2016.

31. Jan-Roblero, J., Garcia-Gomez, E., Rodriquez-Martinez, S., Cancino-Diaz, M.E. and Cancino-Diaz, J.C. (2017) Surface Proteins of Staphylococcus aureus. Chapter of book The Rise of Virulence and Antibiotic Resistance in Staphylococcus aureus. Intech. Avaialble from: https:// www.cdn.intechopen.com/pdfs-wm/53157. Accessed on 15-11-2017.
32. Ghose, S., Allen, M., Hubbard, B., Brooks, C. and Cramer, S.M. (2005) Antibody variable region interactions with Protein A: Implications for the development of generic purification processes. Biotechnol. Bioeng., 92(6): 665-673.

33. Johnson, M. (2013) Rabbit Antibody. Available from: https://www.labome.com/method/Rabbit-Antibody.html. Accessed on 23-01-2017.

34. De-Buysscher, E.V. and Patterson, R.M. (1995) In: Burgess, G.W., editor. Immune Respons. Gadjah Mada University Press, Yogyakarta. p1-9.

35. Tizard, I.R. (2004) An Introduction to Veterinary Immunology. $7^{\text {th }}$ ed. Elsevier, Philadelphia.

36. Yang, L., Biswas, M.E. and Chen, P. (2003) Study of binding between protein a and immunoglobulin $\mathrm{g}$ using a surface tension probe. Biophys. J., 84: 509-522.

37. Zhang, W.D., Wang, W.H. and Jia, S. (2015) Distribution of immunoglobulin $\mathrm{G}$ antibody secretory cells in small intestine of Bactrian camels (Camelus bactrianus). Vet. Res., 11: 222 .

38. Frank, S.A. (2002) Immunology and Evolution of Infectious Disease. Princeton University Press, Princeton, NJ. 